\title{
Evaluation of Health-Related Quality of Life and Its Influencing Factors in Pediatric Patients with Voiding Dysfunction
}

\section{Işeme Bozukluğu Olan Çocuk Hastalarda Yaşam Kalitesi ve Etkileyen Faktörlerin Değerlendirilmesi}

\author{
Emine Gozde Ozdrama Yıldız ${ }^{1 \oplus}$, Gul Ozcelik ${ }^{2}$ \\ ${ }^{1}$ SBU Sisli Hamidiye Etfal Training and Research Hospital, Istanbul, Turkey \\ ${ }^{2}$ SBU Sisli Hamidiye Etfal Training and ResearchHospital, Department of Pediatric Nephrology, Istanbul, Turkey
}

Received: 05.05.2020 / Accepted: 01.12.2020 / Published Online: 29.12.2020

Cite as: Ozdrama Yıldız EG, Ozcelik G. Evaluation of health-related quality of life and its influencing factors in pediatric patients with voiding dysfunction. Med J Bakirkoy 2020;16(4):324-29.

\begin{abstract}
Objective: Health-related quality of life and its influencing factors in pediatric patients with voiding dysfunction and their families were assessed.

Method: The patients who were admitted with urinary incontinence for at least 6 months to the clinics of pediatrics and pediatric nephrology were enrolled in the study. The patients were divided into three groups as daytime urinary incontinence (DUI), enuresis and both DUI and enuresis. The Pediatric Quality of Life InventoryTM (PedsQLTM) was administered to patients and mothers.

Results: A total of 100 patients with voiding dysfunction admitted with urinary incontinence aged from 5 years to 18 years (mean age: $8.8 \pm 2.6)$ were included in the study. The mean dysfunctional voiding symptom score was $15.5 \pm 6.6$ in all groups and significantly higher in the group who experienced both DUI and NE ( $p<0.001)$. No significant difference was observed in terms of mean PedsQL scores of the children and their mothers between groups with urinary incontinence $(65.5 \pm 16$ and $58.4 \pm 13.5$, respectively), but $a$ strong positive correlation was detected between them $(p<0.001)$. The mean PedsQL score for the children aged from 8 years to 12 years was significantly lower than the scores for the children aged from 5 to 7 years $(p<0.05)$. The mean PedsQL score for the children aged between 13, and 18 years was not different from the other age groups.

Conclusion: The early diagnosis and treatment of patients aged from 8 to 12 years who had the lowest PedsQL score is important. Additionally, the success in the improvement of the quality of life of children with voiding dysfunction requires cooperation with
\end{abstract} parents.

Keywords: Enuresis; incontinence, quality of life, voiding dysfunction

Öz

Amaç: İseme bozukluğu olan çocuklarda ve ailelerinde yaşam kalitesinin ve etkileyen faktörlerin incelenmesidir.

Yöntem: Pediatri ve pediatrik nefroloji polikliniklerine idrar kaçırma nedeniyle başvuran ve şikayetleri en az 6 aydır devam eden çocuk hastalar çalışmaya alındı. Hastalar gündüz idrar kaçıranlar, gece idrar kaçıranlar ve hem gündüz hem gece idrar kaçıranlar olmak üzere üç gruba ayrıldı. Çocuklar için Yaşam Kalitesi Ölçeği (ÇiYKÖ) çalışmaya katılan tüm çocuklara ve annelerine uygulandı.

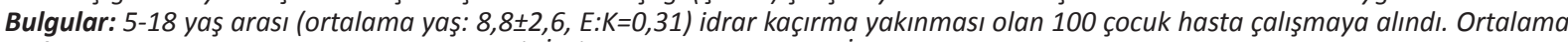
disfonksiyonel işeme semptom skorlaması (DiSS) 15.5 6.6 saptandı. DisS hem gece hem gündüz kaçıran grupta istatistiksel olarak anlamlı daha yüksek saptandı (p<0.001). Anne ve çocukların yaşam kalitesi skorlarında işeme bozukluğu grupları arasında anlamlı farklılık saptanmadı $(58,4 \pm 13,5 ; 65,5 \pm 16)$ fakat kuvvetli pozitif yönde bağıntı saptandı (p<0.001). 8-12 yas grubunda ortalama ÇiYKÖ skoru 5-7 yaş grubuna oranla istatistiksel olarak anlamlı düşük bulundu ( $p<0.05)$. 13-18 yaş grubunun ÇiYKÖ skoru diğer gruplardan farklı değildi.

Sonuç: En düşük ÇiYKÖ skoru saptanan 8-12 yaş grubu çocuk hastaların erken tanı ve tedavisi önem taşımaktadır. Ayrıca işeme bozukıuğu olan çocukların yaşam kalitelerinin iyileştirilmesindeki başarıda ailelerin katkısı önemlidir.

Anahtar kelimeler: Enürezis, idrar kaçırma, yaşam kalitesi, işeme disfonksiyonu 


\section{INTRODUCTION}

Urinary incontinence is a common problem in childhood, and constitutes up to $20 \%$ of visits to pediatric and pediatric urology clinics. Voiding disorders are nonorganic incontinence and classified as enuresis and daytime urinary incontinence (DUI) affecting school children, most commonly girls. It has been shown that enuresis has important effects on children's emotional, social and psychological status, courage, self-esteem and school success ${ }^{(1-8)}$. Urinary incontinence negatively affects quality of life of both children and their parents ${ }^{(9)}$ DUI has negative effects on all of the life qualities including social relationships and future expectations of especially school-age children because DUI is a problem persisting every day ${ }^{(10)}$.

The health-related quality of life (HRQOL) measurement refers to the impact of health and illness on an individual's quality of life. The Pediatric Quality of Life InventoryTM (PedsQLTM), firstly developed by Varni et al. ${ }^{(11)}$, is a widely used instrument to measure pediatric $\mathrm{HRQOL}$ in children aged 2 to 18 years. It queries physical health, emotional and social functionality ${ }^{(11-13)}$. The relation between severity of voiding dysfunction and quality of life and parents' attitudes such as anxiety, discomfort and fear are not clearly established (9). Health related and overall quality of life are useful constructs, and are reduced in children with urınary incontinence based on parental rating. Thus, this study was carried out to assess $\mathrm{HRQOL}$ among children with voiding dysfunction and their parents.

\section{MATERIAL and METHODS}

One hundred and ten children (5-18 years of age) who were admitted with urinary incontinence to the clinics of pediatrics and division of pediatric nephrology were enrolled in this cross-sectional study. If needed, detailed history, physical examination, ultrasonography and advanced imaging were performed. The patients whose complaints were continuing for at least for 6 months were included in the study.

The patients with psychomotor retardation and organic disorders such as spina bifida, neurogenic bladder, obstructive uropathy, vesicoureteral reflux and chronic renal insufficiency and the patients whose parents refused to give written consent were excluded. Ten patients were excluded because of noncompletion of the questionnaires.

The patients were given a questionnare consisting of 17 questions inquiring demographic characteristics, sociocultural level of family, level of mother's education, symptoms of incontinence and accompanying signs. Some $(11 \%)$ of the mothers were illiterate, primary school (69\%), high school (12\%), and university (2\%) graduates. Only the mothers, considered as primary caregivers were enrolled in the study.

The patients were divided into three groups as daytime urinary incontinence (DUI), enuresis and both DUI and enuresis according to International Children's Continence Society (ICCS) criteria ${ }^{(14)}$. The patients were evaluated in consideration of coexistence of urinary tract infection, constipation and/or fecal incontinence, and any treatment (medical therapy/urotherapy). They received.

The patients were evaluated by means of a questionnaire including urinary incontinence, sudden onset of urination and urgency, urine retention maneuvers, weak and an interrupted urine stream. Voiding diaries and uroflowmetry were used in all of the patients with daytime symptoms. The patients who had daytime incontinence were also regarded as having boveractive bladder and daytime incontinence.

The type and severity of voiding dysfunction was evaluated by the dysfunctional voiding scoring system (DVSS) which includes 13 questions scored between 0 and 35 (15). The patients who had scores $\geq 9$, regarded as having voiding dysfunction.

The Pediatric Quality of Life InventoryTM (PedsQLTM 4.0) was administered to pediatric patients with voiding dysfunction and their mothers independently using different appropriate forms. The 23-item PedsQL generic core scales encompass physical (eight items), emotional (five items), social (five items), and school functioning (five items) domains ${ }^{(11,12)}$. Items are reverse scored and linearly transformed to a zero to 100 scale $(0=100,1=75,2=50,3=25,4=0)$ with higher scores. The scoring included: a physical health summary score that represented a physical functioning scale score $(8$ items), and a psychosocial health summary score that was the sum of the items answered in the emotional, 
social, and school functioning scales (15 items). The higher scores indicate better HRQOL. The questionnaires were applied to children aged 5-7 years under the supervision of the doctors and their mothers.

The study protocol was approved by the hospital ethics committee (No:1062, 01/09/2015). Written informed consents were taken from parents.

\section{Statistical Analysis}

Statistical analyses was performed using SPSS 15.0 software (SPSS Inc, Chicago,IL,U.S.A.). Results were expressed as numbers and percentages for categorical variables and means $\pm S D$, minimum, maximum for quantitative variables. If the quantitative variables were normally distributed, the analysis was conducted using Student $t$ test when two groups were compared, and one way ANOVA test for the comparison of more than two groups. If the quantitative variables were not normally distributed, Mann -Whitney $U$ test was used between two groups, and Kruskal Wallis test for more than two groups. The analysis of subgroups were done by Mann- Whitney U test and improved with Bonferroni test. $P$ values of $<0.05$ were considered statistically significant.

\section{RESULTS}

A total of 100 patients with urinary incontinence aged from 5 to 18 years (mean age: 8.8 2.6 ) were included in the study. The demographic characteristics of the patients are shown in Table 1. The patients were divided in three groups according to age as Group 1:5-7 years old (48\%), Group 2:8-12 years old (45\%), and Group 3:13-18 years old (\%7). The patients were divided in three groups according to type of incontinence as Group 1: daytime urinary incontinence (DUI) (16\%), Group 2: enuresis(36\%), and Group 3: both DUI and enuresis (48\%). The mean age of the patients who had both DUI and enuresis was lower than the other two groups $(7.8 \pm 2.6, p<0.01)$.

The mean age of the mothers was $33.8 \pm 6.0$ years. A decrease was observed in the rate of voiding incontinence as the mothers' educational level increased $(p=0.01)$ (Table 1).
Table 1. Demographic characteristics of participants.

\begin{tabular}{|c|c|c|c|c|c|}
\hline & $\begin{array}{c}\text { Total } \\
\text { Patients } \\
(n=100)\end{array}$ & $\begin{array}{c}\text { Group } 1 \\
(n=16)\end{array}$ & $\begin{array}{c}\text { Group } 2 \\
(n=36)\end{array}$ & $\begin{array}{c}\text { Group } 3 \\
(n=48)\end{array}$ & $\mathbf{P}$ \\
\hline $\begin{array}{l}\text { Age (year, } \\
\text { mean } \pm S D)\end{array}$ & $8.5 \pm 2.6$ & $8.0 \pm 2.1$ & $9.7 \pm 2.6$ & $7.8 \pm 2.6$ & \\
\hline \multicolumn{6}{|l|}{ Age group (n,\%) } \\
\hline $5-7$ years & $\begin{array}{c}48 \\
(48 \%)\end{array}$ & $\begin{array}{c}10( \\
62.5 \%)\end{array}$ & $\begin{array}{c}10 \\
(27.8 \%)\end{array}$ & $\begin{array}{c}28 \\
(58.3 \%)\end{array}$ & 0.027 \\
\hline $8-12$ years & $\begin{array}{c}45 \\
(45 \%)\end{array}$ & $\begin{array}{c}6 \\
(37.5 \%)\end{array}$ & $\begin{array}{c}21 \\
(58.3 \%)\end{array}$ & $\begin{array}{c}18 \\
(37.5 \%)\end{array}$ & \\
\hline $13-18$ years & $\begin{array}{c}7 \\
(7 \%)\end{array}$ & 0 & $\begin{array}{c}5 \\
(13.9 \%)\end{array}$ & $\begin{array}{c}2 \\
(4.2 \%)\end{array}$ & \\
\hline \multicolumn{6}{|l|}{ Gender (\%) } \\
\hline Female & $\begin{array}{c}76 \\
(76 \%)\end{array}$ & $\begin{array}{c}14 \\
(87.5 \%)\end{array}$ & $\begin{array}{c}27 \\
(75 \%)\end{array}$ & $\begin{array}{c}35 \\
(72.9 \%)\end{array}$ & 0.489 \\
\hline Male & $\begin{array}{c}24 \\
(24 \%)\end{array}$ & $\begin{array}{c}2 \\
(12.5 \%)\end{array}$ & $\begin{array}{c}9 \\
(25 \%)\end{array}$ & $\begin{array}{c}13 \\
(27.1 \%)\end{array}$ & \\
\hline \multicolumn{6}{|c|}{ Types of daytime incontinence (\%) } \\
\hline $\begin{array}{l}\text { Overactive } \\
\text { bladder }\end{array}$ & $\begin{array}{c}50 \\
(50 \%)\end{array}$ & $\begin{array}{c}14 \\
(87.5 \%)\end{array}$ & 0 & $\begin{array}{c}36 \\
(36 \%)\end{array}$ & 0.001 \\
\hline $\begin{array}{l}\text { Dysfunc- } \\
\text { tional }\end{array}$ & $\begin{array}{c}14 \\
(14 \%)\end{array}$ & $\begin{array}{c}2 \\
(12.5 \%)\end{array}$ & 0 & $\begin{array}{c}12 \\
(25 \%)\end{array}$ & \\
\hline $\begin{array}{l}\text { Age of } \\
\text { mother } \\
\text { (mean } \pm S D \text {, } \\
\text { median) }\end{array}$ & $\begin{array}{c}33.8 \pm 6.0 \\
(22-50)\end{array}$ & $\begin{array}{c}32.4 \pm 5.5 \\
(25-42)\end{array}$ & $\begin{array}{c}33.8 \pm 6.2 \\
(22-48)\end{array}$ & $\begin{array}{c}34.2 \pm 6.0 \\
(23-50)\end{array}$ & 0.525 \\
\hline \multicolumn{6}{|c|}{ Educational level of mother } \\
\hline None & $11(11 \%)$ & $\begin{array}{c}3 \\
(18.8 \%)\end{array}$ & $\begin{array}{c}1 \\
(2.8 \%)\end{array}$ & $\begin{array}{c}7 \\
(14.6 \%)\end{array}$ & 0.010 \\
\hline $\begin{array}{l}\text { Primary } \\
\text { school }\end{array}$ & $69(69 \%)$ & $7(43.8)$ & $\begin{array}{c}32 \\
(88.9 \%)\end{array}$ & $\begin{array}{c}30 \\
(62.5 \%)\end{array}$ & \\
\hline $\begin{array}{l}\text { Secondary } \\
\text { school }\end{array}$ & $6(6 \%)$ & $\begin{array}{c}3 \\
(18.8 \%)\end{array}$ & $\begin{array}{c}1 \\
(2.8 \%)\end{array}$ & $2(4.2 \%)$ & \\
\hline High school & $12(12 \%)$ & $\begin{array}{c}3 \\
(18.8 \%)\end{array}$ & $\begin{array}{c}1 \\
(2.8 \%)\end{array}$ & $\begin{array}{c}8 \\
(16.7 \%)\end{array}$ & \\
\hline University & $2(2 \%)$ & 0 & $\begin{array}{c}1 \\
(2.8 \%)\end{array}$ & & \\
\hline $\begin{array}{l}\text { Febrile urinary } \\
\text { tract }\end{array}$ & $\begin{array}{c}30 \\
(49.2 \%)\end{array}$ & $\begin{array}{c}9 \\
(69.2 \%)\end{array}$ & $\begin{array}{c}8 \\
(47.1 \%)\end{array}$ & $\begin{array}{c}13 \\
(41.9 \%)\end{array}$ & 0.250 \\
\hline \multicolumn{6}{|l|}{ Infection (\%) } \\
\hline $\begin{array}{l}\text { Constipation } \\
\text { (\%) }\end{array}$ & $34(34 \%)$ & $\begin{array}{c}3 \\
(18.8 \%)\end{array}$ & $\begin{array}{c}14 \\
(38.9 \%)\end{array}$ & $\begin{array}{c}17 \\
(35.4 \%)\end{array}$ & 0.353 \\
\hline $\begin{array}{l}\text { Fecal inconti- } \\
\text { nence (\%) }\end{array}$ & $24(24 \%)$ & $8(50 \%)$ & $\begin{array}{c}6 \\
(16.7 \%)\end{array}$ & $\begin{array}{c}10 \\
(20.8 \%)\end{array}$ & 0.027 \\
\hline $\begin{array}{l}\text { Treatment given } \\
\text { (\%) }\end{array}$ & $47(47 \%)$ & $8(50 \%)$ & $\begin{array}{c}17 \\
(47.2 \%)\end{array}$ & $\begin{array}{c}22 \\
(45.8 \%)\end{array}$ & 0.959 \\
\hline
\end{tabular}

Group 1: Daytime incontinence

Group 2:Enuresis

Group 3: Daytime incontinence and enuresis

$P<0.05$ is statistically significant

The DVSS and PedsQL scores of the patients and mothers are shown in Table 2. The mean DVSS was $15.5 \pm 6.6$ in all groups and significantly higher in the group who experienced both DUI and enuresis $(p<0.001)$. No significant difference was observed in terms of the mean PedsQL score between children and their parents ( $65.5 \pm 16$ and $58.4 \pm 13.5$, respectively) 
Table 2. Voiding symptom scores and mean PedsQL scores according to groups

\begin{tabular}{|c|c|c|c|c|c|}
\hline & $\begin{array}{c}\text { Total } \\
\text { patients } \\
(n=100)\end{array}$ & $\begin{array}{c}\text { Group } 1 \\
(n=16)\end{array}$ & $\begin{array}{c}\text { Group } 2 \\
(n=36)\end{array}$ & $\begin{array}{c}\text { Group } 3 \\
(n=48)\end{array}$ & p \\
\hline $\begin{array}{l}\text { DVSS } \\
\text { (mean } \pm S D \text {, } \\
\text { range) }\end{array}$ & $\begin{array}{c}15.5 \pm 6.6 \\
(2-31)\end{array}$ & $\begin{array}{l}12 \pm 4.6 \\
(6-22)\end{array}$ & $\begin{array}{c}11.3 \pm 4.9 \\
(2-30)\end{array}$ & $\begin{array}{c}19.7 \pm 5.7 \\
(10-31)\end{array}$ & $<0.001$ \\
\hline \multicolumn{6}{|c|}{ Total PedsQLscore (mean \pm SD, range) } \\
\hline Patients & $\begin{array}{c}65.5 \pm 16 \\
(9.8-100)\end{array}$ & $\begin{array}{c}65.5 \pm 16 \\
(30.4-95.7)\end{array}$ & $\begin{array}{c}67.5 \pm 14.6 \\
(39.1-97.2)\end{array}$ & $\begin{array}{r}64.7 \pm 16.7 \\
(9.8-100)\end{array}$ & 0.619 \\
\hline Mothers & $\begin{array}{c}58.4 \pm 13.5 \\
(28.3-93.5)\end{array}$ & $\begin{array}{l}54.7 \pm 13.7 \\
(34.8-87)\end{array}$ & $\begin{array}{c}57.6 \pm 13.4 \\
(28.3-84.8)\end{array}$ & $\begin{array}{c}60.2 \pm 13.5 \\
(31.5- \\
93.5)\end{array}$ & \\
\hline
\end{tabular}

DVSS $=$ Dysfunctional voiding symptom score; PedsQL=Pediatric quality of life inventory

Group 1: Daytime incontinence

Group 2:Enuresis

Group 3: Daytime incontinence and enuresis

$P<0.05$ is statisticaly significant

The comparison of PedsQL scores according to demographic characteristics and accompanying conditions is shown in Table 3. The mean PedsQL score for children Table 3. The comparison of demografic characteristics with mean PedsQL scores of the patients

\begin{tabular}{|c|c|c|c|}
\hline & \multicolumn{2}{|c|}{$\begin{array}{l}\text { Total PedsQL scores of the } \\
\text { patients }\end{array}$} & \multirow[t]{2}{*}{$\mathbf{P}$} \\
\hline & Mean $\pm S D$ & Median & \\
\hline \multicolumn{4}{|l|}{$\begin{array}{l}\text { Age of the } \\
\text { patients }\end{array}$} \\
\hline $5-7$ years & $70.0 \pm 14.8$ & 69.6 & \multirow[t]{3}{*}{0.020} \\
\hline $8-12$ years & $60.8 \pm 15.5$ & 59.8 & \\
\hline $13-18$ years & $64.6 \pm 20.6$ & 57.6 & \\
\hline \multicolumn{4}{|l|}{ Gender } \\
\hline Female & $66.1 \pm 16.0$ & 65.9 & \multirow[t]{2}{*}{0.473} \\
\hline Male & $63.4 \pm 16.2$ & 63 & \\
\hline \multicolumn{4}{|l|}{$\begin{array}{l}\text { Febrile urinary } \\
\text { tract infection }\end{array}$} \\
\hline Present & $60.3 \pm 18.9$ & 59.7 & \multirow[t]{2}{*}{0.018} \\
\hline Absent & $70.3 \pm 12.4$ & 69.6 & \\
\hline \multicolumn{4}{|l|}{ Constipation } \\
\hline Present & $64.5 \pm 17.5$ & 64.7 & \multirow[t]{2}{*}{0.655} \\
\hline Absent & $66.0 \pm 15.3$ & 67.6 & \\
\hline \multicolumn{4}{|l|}{$\begin{array}{l}\text { Fecal } \\
\text { incontinence }\end{array}$} \\
\hline Present & $60.0 \pm 17.6$ & 60.3 & \multirow[t]{2}{*}{0.052} \\
\hline Absent & $67.2 \pm 15.2$ & 69.6 & \\
\hline \multicolumn{4}{|l|}{ Treatment } \\
\hline Yes & $62.4 \pm 14.8$ & 60.9 & \multirow[t]{2}{*}{0.073} \\
\hline No & $68.2 \pm 16.7$ & 69.6 & \\
\hline
\end{tabular}

PedsQL= Pediatric quality of life inventory

$P<0.05$ is statistically significant aged from 8 years to 12 years was significantly lower than the scores for the children aged from 5 to 7 years $(p<0.05)$. The mean PedsQL score of the patients with febrile urinary tract infection was significantly lower than those without $(p<0.05)$. No difference was detected between PedsQL scores of patients whether they had constipation and/or fecal incontinence, and whether they were given treatment or not $(p>0.05)$.

A weak negative correlation was observed between PedsQL scores and the age of patients and mothers ( $p<0.01, r=0.277$ and $p<0.05, r=0.204$, respectively). A strong positive correlation was observed between PedsQL scores of the patients and parents $(p<0.001)$ (Table 4).

Table 4. The association between mean PedsQLscore of the patients and the age of mother, Voiding symptom score and PedsQLscore of the mothers

\begin{tabular}{|l|c|c|}
\hline \multirow{2}{*}{} & \multicolumn{2}{|c|}{ Total PedsQL score of the patients } \\
\cline { 2 - 3 } & $r$ & $\mathrm{P}$ \\
\hline Age of patients & -0.277 & 0.005 \\
\hline DVSS & -0.470 & 0.640 \\
\hline Age of the mothers & -0.204 & 0.042 \\
\hline $\begin{array}{l}\text { Total PedsQL score of } \\
\text { the mothers }\end{array}$ & 0.607 & $<0.001$ \\
\hline
\end{tabular}

DVSS = Dysfunctional voiding score; PedsQL= Pediatric quality of life inventory

$P<0.05$ is statistically significant

\section{DISCUSSION}

There are limited number of studies investigating emotional and behavioral changes, and quality of life in patients with voiding dysfunction ${ }^{(4-9)}$. We evaluated HRQOL and influencing factors in pediatric patients aged 5-18 years who had various voiding dysfunction. Most of the children in our study were in the group of patients who had both DUI and enuresis, and $76 \%$ of our patients were female. The mean age of the patients with both DUI and enuresis was lower than the patients who had solely DUI or enuresis $(p<0.01)$. Although PedsQL score of this group was good, symptoms of these children with both DUI and enuresis exerted much more adverse effects such as anxiety and discomfort on parents, and thus may lead to admittance to clinics earlier.

In concordance with the previous studies, the mean age of the patients with only enuresis was higher than 
the other two groups ${ }^{(16)}$, which was attributed to the parents' thought that enuresis will resolve spontaneously with time.

The educational level of the mother was considered as a socio-cultural index in many studies. It has been reported that urinary incontinence was more common among families who had low socio-cultural level ${ }^{(8,17)}$. Similarly, we observed that with increasing level of education of the mother, the rate of incontinence was decreased $(p=0.01)$.

It is important to identify accompanying disorders such as urinary tract infection and constipation in these patients with urinary incontinence since improvement of these conditions affects the treatment success ${ }^{(16,17)}$. We detected concomitant urinary tract infection in $30 \%$, constipation in $34 \%$, and fecal incontinence in $24 \%$ of our patients most commonly in the patients with both DUI and enuresis. Logan BA et al. ${ }^{(18)}$ reported that bladder and bowel dysfunction is frequent and an overlooked problem in children with voiding dysfunction and mentioned that $60 \%$ of these patients had at least one psycihosocial factor. In another study ${ }^{(19)}$, it has been reported that $31.1 \%$ of 429 children with nocturnal enuresis aged between 5 and 16 years had at least one lower urinary tract symptom (LUTS) and $16.3 \%$ of them had a comorbid condition. We did not determine neuropsychiatric disorder in this study. All of the groups, especially the group with DUI had frequently accompanying symptoms, which represents importance of the treatment and its urgency in these children.

The DVSS score was found higher in the patients who experienced both DUI and enuresis in our study. DVSS is an important measurement tool in diagnosis, followup, treatment and improvement of voiding dysfuction. DVSS and Pediatric Urinary Incontinence QOL tool (PINQ) were performed in pediatric patients aged from 5 to 11 years and a correlation was found between DVSS and PIN-Q scores of the patients and their parents in the study of Thibodeau et al. ${ }^{(9)}$. In contrast with the previous studies, we found no association between voiding dysfunction symptoms and PedsQL scores.

Compatible with the literature ${ }^{(16,20,21)}$, the results of this study showed low PedsQL scores in children with voiding dysfunction. No significant difference was observed between the mean PedsQL total scores of our groups and their parents. Deshpande et al. ${ }^{(22)}$ reported that quality of life was lower in older children with incontinence, female gender and nonwhite ethnicity and drawn the attention of the clinicians to the fact that urinary incontinence had different effects on children with different age groups and ethnicity.

We also observed a weak correlation between PedsQL scores and age of the patients and their mothers and a strong correlation between PedsQL scores and the parents' quality of life. In various studies, the quality of life has been reported to be similar in children with incontinence and their parents, but no change was observed at diagnosis and during treatment. It has been considered that parents overlooked emotional improvement of their children with DUI, or they still had negative affect ${ }^{(7,10)}$. Therefore, it is mandatory that quality of life of children and parents must be complementary for raising awareness about voiding dysfunction symptoms at early ages by parents, leading to early diagnosis and treatment.

The limitations of current research include; performing a single measurement instead of multiple measurements for evaluating changes over time, failure to compare these changes with those of the healthy children and being a single center experience with a small number of patients.

In conclusion, urinary incontinence affects social, emotional, and behavioral aspects adversely and lowers the quality of life both of the children and their parents. Early diagnosis of urinary incontinence should motivate patients and also their parents, leading to increased success of the treatment given, especially in the patients aged from 8 to 12 years who had the lowest PedsQL scores in our study. The healthcare professionals should be informed about the effects of enuresis on the quality of life of children and be able to help and alleviate the negative effects of psychological consequences to the child, as well as to the parents.

Ethics Committee Approval: Şişli Etfal Hospital Clinical Research Ethics Committee approval was received (01/09/2015; 545).

Conflict of Interest: No conflict of interest was declared by the authors.

Funding: No funding was used for this study. Informed Consent: Informed consent was obtained from all individual participants included in the study. 


\section{REFERENCES}

1. Sousa E Silva GJ, Sammour SNF, Ferraro AA, Koch VHK. Study of the profile of behavioral problems and quality of life indexes in a pediatric cohort of monosymptomatic enuresis. J Pediatr (Rio J). 2019;95(2):188-93. https://doi.org/10.1016/j.jped.2017.12.006

2. Fagundes SN, Lebl AS, Azevedo Soster L, Sousa E Silva GJ, Silvares EF, Koch VH. Monosymptomatic nocturnal enuresis in pediatric patients: multidisciplinary assessment and effects of therapeutic intervention. Pediatr Nephrol. 2017;32(5):843-51. https://doi.org/10.1007/s00467-016-3510-6

3. Ucer O, Gumus B. Quantifying subjective assessment of sleep quality, quality of life and depressed mood in children with enuresis. World J Urol. 2014;32(1):239-43. https://doi.org/10.1007/s00345-013-1193-1

4. Hägglöf $B$, Andrén $O$, Bergström E, Marklund L, Wendelius M. Self-esteem in children with nocturnal enuresis and urinary incontinence: improvement of self-esteem after treatment. Eur Urol. 1998;33(Suppl. 3):16-9 https://doi.org/10.1159/000052236

5. Liu X, Sun Z, Uchiyama M, Li Y, Okawa M. Attaining nocturnal urinary control, nocturnal enuresis, and behavioral problems in Chinese children aged 6 through 16 years. J Am Acad Child Adolesc Psychiatry. 2000;39(12):1557-64. https://doi.org/10.1097/00004583-200012000-00020

6. Kara OD, Ozdemir K, Dincel N, Kutlu A, Yilmaz E, Canturk G, et al. Evaluation of life qualities on children with monosymptomatic enuresis nocturia. J Contemporary Med. 2015;5(2):83-7. https://doi.org/10.16899/ctd.49503

7. Equit M, Hill J, Hübner A, von Gontard A. Health-related quality of life and treatment effects on children with functional incontinence, and their parents. J Pediatr Urol. 2014;10(5):922-8. https://doi.org/10.1016/j.jpurol.2014.03.002

8. Kilicoglu AG, Mutlu C, Bahali MK, Adaletli H, Gunes H, Duman $\mathrm{HM}$, et al. Impact of enuresis nocturna on health-related quality of life in children and their mothers. J Pediatr Urol. 2014;10(6):1261-6. https://doi.org/10.1016/j.jpurol.2014.07.005

9. Thibodeau BA, Metcalfe P, Koop P, Moore K. Urinary incontinence and quality of life in children. J Pediatr Urol. 2013;9(1):7883. https://doi.org/10.1016/j.jpurol.2011.12.005

10. Ikeda H, Oyake C, Oonuki Y, Fuyama M, Watanabe T, Kyoda T, et al. Complete resolution of urinary incontinence with treatment improved the health-related quality of life of children with functional daytime urinary incontinence: a prospective study. Health Qual Life Outcomes. 2020;18(1):14. https://doi.org/10.1186/s12955-020-1270-2

11. Varni JW, Seid M, Rode CA. The PedsQL: measurement model for the pediatric quality of life inventory. Med Care. 1999;37(2):12639. https://doi.org/10.1097/00005650-199902000-00003
12. Varni JW, Burwinkle TM, Lane MM. Health-related quality of life measurement in pediatric clinical practice: an appraisal and precept for future research and application. Health Qual Life Outcomes. 2005;3:34. https://doi.org/10.1186/1477-7525-3-34

13. Sonmez S, Basbakkal Z. A validation and reliabilition study for the Pediatric Quality of Life Inventory (PedsQL 4.0) on Turkish children. Turkiye Klinikleri J Pediatr. 2007;16(4):229-37. Available from: https://www.turkiyeklinikleri.com/article/tr-turk-cocuklarinin-pediatrik-yasam-kalitesi-4-envanterinin-pedsql-4-gecerlilikve-guvenilirlik-calismasi-48876.html

14. Austin PF, Bauer SB, Bower W, Chase J, Franco I, Hoebeke P, et al. The standardization of terminology of lower urinary tract function in children and adolescents: Update report from the standardization committee of the International Children's Continence Society. Neurourol Urodyn. 2016;35(4):471-81. https://doi.org/10.1002/nau.22751

15. Farhat W, Bägli DJ, Capolicchio G, O'Reilly S, Merguerian PA, Khoury $A$, et al. The dysfunctional voiding scoring system: quantitative standardization of dysfunctional voiding symptoms in children. J Urol. 2000;164(3 Pt 2):1011-5. https://doi.org/10.1016/S0022-5347(05)67239-4

16. Sarici H, Telli O, Ozgur BC, Demirbas A, Ozgur S, Karagoz MA. Prevalence of nocturnal enuresis and its influence on quality of life in school-aged children. J Pediatr Urol. 2016;12(3):159.e1-6. https://doi.org/10.1016/j.jpurol.2015.11.011

17. Gur E, Turhan P, Can G, Akkus S, Sever L, Güzelöz S, et al. Enuresis: prevalence, risk factors and urinary pathology among school children in Istanbul, Turkey. Pediatr Int. 2004;46(1):58-63. https://doi.org/10.1111/j.1442-200X.2004.01824.x

18. Logan BA, Correia K, McCarthy J, Slattery MJ. Voiding dysfunction related to adverse childhood experiences and neuropsychiatric disorders. J Pediatr Urol. 2014;10(4):634-8. https://doi.org/10.1016/j.jpurol.2014.06.012

19. Shah S, Jafri RZ, Mobin K, Mirza R, Nanji K, Jahangir F, et al. Frequency and features of nocturnal enuresis in Pakistani children aged 5 to 16 years based on ICCS criteria: a multi-center cross-sectional study from Karachi, Pakistan. BMC Fam Pract. 2018;19(1):198. https://doi.org/10.1186/s12875-018-0876-5

20. Ozcetin M, Uluocak N, Yilmaz R, Atilgan D, Erdemir F, Karaarslan $E$. The evaluation of urinary incontinence in preschool age children. Çocuk Dergisi. 2010;10(2):75-81. Available from: https:// dergipark.org.tr/tr/download/article-file/1328212 https://doi.org/10.5222/j.child.2010.075

21. Veloso LA, Mello MJ, Ribeiro Neto JP, Barbosa LN, Silva EJ. Quality of life, cognitive level and school performance in children with functional lower urinary tract dysfunction. J Bras Nefrol. 2016;38(2):234-44. https://doi.org/10.5935/0101-2800.20160033

22. Deshpande AV, Craig JC, Smith GH, Caldwell PH. Factors influencing quality of life in children with urinary incontinence. J Urol. 2011;186(3):1048-52. https://doi.org/10.1016/j.juro.2011.04.104 